\title{
DETERMINANTS OF MICROFINANCE RePAYMENT Performance: A STUdy OF SOUTH African MFIs
}

\author{
Jonathan Muchnick* \\ University of the Witwatersrand \\ Joni.Muchnick@gmail.com
}

Received: November 2013

\author{
Umakrishnan Kollamparambi|\# \\ University of the Witwatersrand \\ uma.kollamparambil@wits.ac.za
}

Accepted: December 2014

\begin{abstract}
This empirical article looks at the determinants of joint-liability lending repayment performance among the two largest microfinance group-lending organisations in South Africa. Most empirical work on repayment performance does not focus on the characteristics of group-based lending methodologies. This study is an attempt to fill this gap in South African microfinance literature. The results of the logit analysis uncover interesting findings. The study uses the Poverty Wealth Ranking score variable to show the ability of individuals with little or no collateral to be good borrowers. Smaller loan sizes are found to perform better than larger loans. An important contribution of the article is analysing the impact of group homogeneity on repayment performance. It was found that large group sizes and groups made up of male and female (as opposed to groups with only females) can have a negative impact on repayment performance. The findings also indicate that the more homogeneous a group in industry type the better the repayment performance.
\end{abstract}

Keywords

Microfinance, Joint-liability lending, Repayment performance, Logit regression, South Africa

*Mr J Muchnick is an M.Com (Economics) student at the School of Economic and Business Sciences, University of Witwatersrand, South Africa.

"Prof $\boldsymbol{U}$ Kollamparambil is an associate professor in the School of Economic and Business Sciences, University of Witwatersrand, South Africa. 


\section{INTRODUCTION}

The lack of credit is generally seen as one of the main reasons for persistent poverty in developing economies. Usually, the poor have no access to loans from the formal banking system because of their inability to provide collateral. Furthermore, the cost for banks to monitor, screen and enforce loan contacts of the poor is not economical relative to the associated loan size. However, the poor in developing economies have increasingly gained access to small loans with the help of the growing number of microfinance programmes. The main reason for the expansion in the microfinance industry is believed to be a result of the innovations in lending techniques first popularised by Nobel laureate Dr Mohammed Yunus through the establishment of Grameen Bank in Bangladesh. Since then there has been a significant acceleration in microfinance institutions being set up globally with thousands of microcredit institutions reaching millions of clients. Historically, the majority of these clients were among the poorest at the point of taking their first loan, with $83.4 \%$ of the poorest clients being female (Daley-Harris 2007).

The innovative lending mechanism that made microlending to the poor without collateral possible is joint-liability group lending. In joint-liability lending, the group of borrowers is made responsible for the repayment of their loan. Thus, if one member of the group doesn't repay their loan, the others will have to contribute to ensure repayment to prevent default. The main reason the group will cover an individual's missed or shortfall in payment is a result of their dependence on future credit, which will not be provided if the group as a whole does not meet its obligation. This method of lending entices the group members to screen each other and exert peer pressure in order to reduce the risk of having to repay other members' loans. Thus, joint-liability group lending stimulates screening, monitoring and enforcement of contracts among the borrowing group, reducing the agency costs of the lender and improving the repayment performance of groups. This assists in mitigating the challenges of adverse selection and moral hazard by applying peer monitoring and community pressure on borrowers, which substantially reduced the cost of lending compared to conventional lending through formal institutions. Most models in the literature focus on explaining its implications for reducing information asymmetries.

Another important issue discussed in the literature is the trade-off between the financial sustainability and outreach of microfinance programmes. Since most microfinance institutions (MFIs) are not backed by the collateral of borrowers, bad loan repayment can endanger the capital of a financial institution in the long run. The loan losses will deplete capital and reduce the number of future loans that can be distributed. In order for an MFI to become sustainable it must be independent of subsidies. However, it cannot be independent from subsidies unless it can cover all its operational expenses. Thus, good repayment performance is essential to the sustainability of an MFI and is usually used to assess how an MFI is performing. This research will allow microfinance organisations to optimally allocate capital by designing efficient lending strategies to ensure programme sustainability. Using data from two of the largest joint-liability group lending MFIs in the country, this article aims to provide insight into the optimal programme design and identify the determinants of repayment performance.

The article continues with a review of theoretical and empirical literature on joint-liability lending globally followed by the development of microfinance in South Africa in section 2 and 3 respectively. Section 4 details the information on the two microfinance organisations used in the analysis viz., Marang Financial Services and Small Enterprise Foundation. This is followed by a discussion on data summary and a detailed explanation of variables in section 5 . The 
econometric estimation and discussion of results make up section 6. Finally, the article concludes with an explanation of the empirical results.

\section{REVIEW OF THE LITERATURE}

There are several theoretical models that confirm that joint-liability group lending leads to more effective repayment performance through peer monitoring, peer pressure and peer selection. Stiglitz (1990) and Varian (1990) examine how joint-liability can motivate borrowers in a group to screen and monitor efforts, in order to reduce the moral hazard issues involved in lending to those with no collateral.

Stiglitz (1990) showed how a lender can benefit from peer monitoring among borrowers. By requiring one borrower to pay if another borrower in the group defaults (introduction of peer monitoring), borrowers choose less risky group members. Varian (1990) modelled the principal of mutual insurance among group members to explain the success of Grameen Bank. He showed that if risk-averse individuals are able to insure each other across different states unobservable by the principal, the principal stands to benefit, which is not the case where there is no mutual insurance.

Using game theory methodology, Besley and Coate (1995) showed that high levels of social ties facilitate peer pressure, which has a positive effect on repayment performance in group lending. A few years later, Ghatak (1999) provided a theory to explain how joint-liability credit contracts used by group lending schemes can achieve high repayment rates even when borrowers have no collateral to offer. He analysed how programmes that use joint liability utilise local information that borrowers have about each other's projects through self-selection of group members in the group formation stage. The article argues that the joint-liability methodology with selfselection will attract the safe borrower only, and the risky borrowers will be screened out. Thus the group homogeneity and social ties are expected to increase the repayment performance due to more efficient group dynamics.

There has been a wealth of comprehensive theoretical literature and it seems that there was a large lag before empirical literature started to add to the group lending body of knowledge. This is due to a lack of reliable data on the workings of these programmes and the general behaviour of their practices. In the first attempt to fill this gap, Wenner (1995) examines the determinants of repayment performance of groups, using the data of 25 Costa Rica credit groups. He tests whether the selection mechanism impacts repayment performance and whether group members use local information for screening their peers. His analysis shows that lending groups use local information to select their peers and this improves the repayment performance. His study also suggests that loan performance is improved by savings mobilisations among borrowers from more isolated the communities with less access to other sources of credit."

Sharma and Zeller (1997) did an empirical analysis of repayment performance using data on 128 groups belonging to three group-based credit programmes in Bangladesh. They did their analysis using a Tobit model with the following hypothesised determinants: group size, size of loans, loan rationing enterprise mix within groups, demographic characteristics, social ties and idiosyncratic shocks. Some of their findings include: repayment problems increase when there are more relatives in the same group; if borrowers are more credit rationed this increases repayment performance; and groups that were formed using a self-selection process show a better repayment performance. Zeller (1998) investigated the effect of intergroup pooling of 
risky projects by controlling for community-level and programme design factors that influence the repayment rate of group loans as well as the effects of homogeneity of group member projects on repayment performance. The econometric analysis is based on a random sample of 146 groups from six different group lending programmes in Madagascar. He concluded that the diversification of the risk improves performance. He uses a social cohesion index, which counted the number of common demographic and social characteristics among group members, and this was found to be significantly linked with the repayment rate. Furthermore, he found that certain repayment improving characteristics are more prevalent in less remote areas, which is contrary to the findings of Wenner (1995).

Wydick (1999) used a logit estimator on a large number of interesting variables to measure screening, monitoring and enforcement within groups. He used a data set consisting of 137 groups from a group-based lending programme in Guatemala and found that the existence of social ties with groups reduces the effectiveness of peer pressure members put on each other to repay the loans. This conclusion is contrary to the theory of Besley and Coate (1995) and Ghatak (1999). He found a positive significant relationship between variables that are used to proxy monitoring within groups and repayment performance.

Bhatt and Tang (2002) analysed the determinants of repayment performance using group-based lending programmes in the United States. They used data from the oldest four microcredit programmes in the country and found that the determinants of repayment performance in the United States is similar to third world countries. They found educational level of the borrower, proximity to the lending programme, lower transaction costs, and greater perceived sanction for non-repayment to have a positive impact on repayment performance. They found no significant impact of homogeneity as a group trait on repayment."

Godquin (2004) used 1629 observations of the following three microfinance organisations: Grameen Bank, Bangladesh Rural Advancement Committee, and Bangladesh Rural Development Board from Bangladesh. He analysed the impact of social ties, dynamic incentive mechanisms, social intermediation and group homogeneity on group lending performance. He found a negative relationship between social ties and loan performance, which supports the conclusion of Wydick (1999). He found no relationship between group homogeneity and repayment performance. Credit rationing, a measure of the dynamic incentive, was found to be positive but insignificant.

Cassar et al. (2007) used a field experiment from South Africa and Armenia to investigate the effect of social capital on group loan performance. Using trust and microfinance games they found evidence to suggest that social homogeneity and personal trust between group members are more influential with a positive effect on loan performance than acquaintanceship or social trust between members, which had little effect. They also suggest that those who have received payment help from other members in the group are more likely to contribute in the future.

Using questionnaires and an analysis of 3000 microfinance companies in South Africa, Vuuren (2011) created an average profile of good and bad microfinance clients in South Africa. He looked at the following characteristics: average age; gender; average loan amount; average term; average number of loans over a five-year period; and the average credit exposure over a five-year period. He found that the average age, average number of loans in five years and the average credit exposure over five years is less for the average bad microfinance client and loan size, and loan terms are greater for the average bad microfinance clients compared to the average good microfinance clients. However, Vuuren (2011), like the authors of other 
microfinance studies in South Africa, did not focus on the characteristics of group-based lending methodologies.

Microfinance as a tool to alleviate poverty has been used widely, and further studies have been conducted using data from Armenia, Peru, Canada, Thailand, Ethiopia and many more. In summary, the existing empirical literature puts emphasis on the importance of social ties, risk diversification / group homogeneity, intergroup insurance, gender, group size and locations as impacting the groups' repayment performance. Risk diversification and group solidarity appear to have an unchallenged positive effect on loan repayment. Social ties and geographical remoteness tend to have a more ambiguous impact, with social ties tending to have a negative repayment impact. In the view of many of the authors mentioned above as well as others, there is a call to do more empirical research on the impact of microfinance on poverty alleviation as well as further investigate the efficiency of the programme designs. This article contributes to the second issue by identifying determinants of repayment performance.

\section{MICROFINANCE DEVELOPMENT IN SOUTH AFRICA}

Microfinance has been prevalent in Asia and Latin America for decades, but South Africa has experienced a lag in the implementation of this development strategy. As a result the programmes are generally less advanced and smaller. The microfinance revolution took a different path post-apartheid after the economy's structure underwent a major transformation. The emergence of the nation from apartheid saw a great drive by financial institutions which now had access to a segment of the market that they had previously had minimal or no exposure to. In 1992, the exemption of the Usury Act was signed into South African legislation. This helped deregulate the microfinance industry by eliminating price controls on small loans. This deregulated environment set by the government helped drive a major expansion of the microfinance industry (Mohane et al., 2002). At the end of apartheid the majority of South Africans had little or no access to credit or financial institutions. Post-apartheid a lot of ground has been made up on this front, but a large part of the population are still marginalised. Prior to the end of the regime small microenterprise activities were supported by NGOs. Some of these NGOs operating in the former homelands include the Rural Finance Facility, the Get Ahead Foundation, and the Small Enterprise Foundation. As a result of the lack of interest by commercial banks to provide financial services such as credit to the poor, the government created Khula and the South African Microfinance Apex Fund (SAMAF) as wholesale finance institutions which operate through a network of channels to supply funding to small business (Calvin and Coetzee, 2009).

The expanding microfinance industry was left open to abuse following the 1992 Usury Act exemption, and as a result in 1999 the government amended the legislation and established the Microfinance Regulatory Council (MFRC). This has since been replaced by the National Credit Regulator (NCR), established with the promulgation of the National Credit Act of 2005 (Calvin and Coetzee, 2009). The act aims to protect consumers and the financial sector, including the microfinance sector, through a well-defined regulatory framework.

The South African microfinance sector today can be divided into microenterprise lenders, financial cooperatives, salary-based lenders, microlenders, alternative banks, primary banks, and retail development finance institutions (BANKSETA 2013). For the purposes of this article, microenterprise lenders are of interest. The significant microfinance organisations are the Small Enterprise Foundation, Marang Financial Services, and Women's Development Businesses, with 
more than 20000 active loans each. The remaining institutions, Akanani Financial Services, Tetla Financial Services, Tiisha Financial Services (all of which follow a group lending methodology), have fewer than 3000 active loans each. Get Ahead Finance, which became Marang Financial Services, was the first to introduce group lending into South Africa in 1987, and was followed by Women's Development Business in 1991 and Small Enterprise Foundation in 1992, with all three starting as Grameen Bank replicators, using group lending methodologies.

\section{PROGRAMME DESCRIPTION}

This study uses the data provided by the two biggest group-based microenterprise lenders in South Africa, namely Small Enterprise Foundation and Marang Financial Services. The two organisations use similar group dynamic incentives to enforce repayment. One of the main reasons why the group liability lending system used by these microfinance institutions is so effective is the loan recipient's reliance on future credit. Knowing that a bad payment will jeopardise essential future cash flow is a strong incentive to maintain a good repayment performance. In general, these individuals are considered risky, as they have no wealth in the form of collateral to offer in the case of default, which will severely impact the institution's loss should default occur. The details of the microfinance institutions that have been used in this analysis follow below.

\subsection{Small Enterprise Foundation}

The Small Enterprise Foundation (SEF) is an internationally recognised non-profit microfinance institution and has poverty alleviation as its main focus. It was incorporated under Section 21 of the Companies Act and operates as a microfinance NGO. The institution was established and started distributing loans in 1992. These loans aimed at extending credit to those who live below half the poverty line in the poorest regions of South Africa. The performance summary shows that since inception the organisation has disbursed 412820 loans to the value of R532 million in December 2007 (SEF website). SEF operated only in the Limpopo province up to 2001, after which it expanded operations all over South Africa with 49 different branches.

SEF started off with a single Microcredit Programme (MCP) that targeted existing microenterprises. The idea behind the programme was to develop a model that the organisation could scale up in order to reach thousands of very poor potential clients. However, SEF discovered that this programme was not reaching the deeply impoverished, and in practice the majority of the loans were being taking up by non-poor people hoping to get larger loans in the future. To combat this challenge, in 1996 SEF launched the Tshomisano Credit Programme (TCP). TCP is exclusively for very poor individuals who live below half the poverty line, with the majority of participants being female (Hietalahti and Linden 2006).

SEF makes use of a group-based lending methodology modelled on Grameen Bank's solidarity lending system. The Urban Resource Centre (2003) details the lending strategy of SEF. According to it potential members form themselves into groups of five, which are rigorously tested before they are officially recognised by SEF. Upon recognition groups are eligible to apply for loans, which they collectively guarantee. Within the group there cannot be any member of the same family, and an age difference of a maximum of twenty years is allowed in one group. Furthermore, members must live within walking distance of one another. The loan amounts range from R500 to R12 000. In general, the initial loans are small and increase in value as individuals 
pay back their loans. This is one way to mitigate the risk of taking large losses, and it allows individuals and groups to prove themselves as good borrowers. The process where the individual pays back the loan and then applies for another loan is referred to as the loan cycle. Normally, higher loan cycles are associated with larger loans. The reason individuals are referred to and not groups in this case is because groups consist of individuals on different cycles, something that is often encouraged by microfinance institutions. Another influencing factor which impacts whether sequential loan cycles increase in value is the percentage saved by individuals. Individuals are required to save $2 \%$ of their loan at every fortnightly/monthly opportunity, which allows them to increase loan size by 1.4 times after approximately three cycles. SEF has five different instalment payment schedules consisting of eight fortnights, twelve fortnights, four months, six months and ten months.

\subsection{Marang Financial Services}

Marang Financial Services (Marang) is a microfinance institution that offers credit to microenterprises. In 2000, the institution was established to take over the operations of Get Ahead Financial Services (GAFS) and the Rural Finance Facility (RFF). In July 2001, the company was converted into a section 21 non-profit organisation, positioned at the frontier of poverty alleviation. It is second largest pro-poor microfinance institutions in South Africa after SEF. Marang focuses predominantly on small-scale entrepreneurs in rural areas, using a group-based lending methodology where members take one loan and each member carries joint liability for the loans. In 2011 it disbursed R100 million to 43712 clients and has a presence in five provinces with 24 branches in operation.

Marang targets predominantly adult women excluded from accessing financing from the formal financial sector due to a lack of adequate collateral. The self-formed borrowing groups range up to a maximum of ten members, with the majority of groups consisting of five members. The loans have a period of four to nine months, with the majority of the loans being four months, and the loan value ranges from R500 to R15 000 over a period. The first cycles range from R500 to R2 000 and then they normally increase incrementally per cycle. Monthly instalments must be paid on due dates selected by clients, and the key part of the lending methodology is that the whole group is responsible for the entire loan. This forms the group guarantee system. Groups are required to contain members who know each other well, live close to each other, trust one another and are supportive of each other's business. The group members are encouraged to assess the legitimacy and sustainability of each other's businesses. This is one way of reducing monitoring costs and getting the clients to do an in-depth assessment of their group members without the major problem of information asymmetries. It serves as a business filtration system as an attempt to remove bad borrowers.

\section{DATA AND DESCRIPTIVE STATISTICS}

This empirical analysis makes use of two separate cross-sectional data sets provided by SEF and Marang detailing several explanatory variables together with repayment performance. In line with their lending methodology, the microfinance institutions record only the repayment performance of the groups as a whole. This implies that the institutions don't differentiate between individuals that contribute toward a group's loan instalment as long as the members of a group cover the instalment amount. This implies that the raw data had a mismatch of individual characteristic with group repayment performance identifiable with a unique group 
loan code. This mismatch is solved by aggregating, averaging and distinguishing the different group information to investigate the impact of the different group characteristics on repayment performance.

TABLE 1 presents the data summary of some of the important variables of the SEF and Marang Financial Services data sets. The two lenders do not differ significantly as regards the average number of members and their age. However, the average loan size seems to be higher for Marang as compared to SEF. The loan cycle, however, is higher for SEF. TABLE 2 provides a further breakdown of the Marang data set across group size and location. The data consists of 1994 group with 8223 individual loans. The majority of the groups have female members only, with $17 \%$ of the groups having at least one male.

TABLE 3 presents SEF's data. The majority of the SEF loan book is made up of the Tshomisano Credit programme (TCP) programme data to represent the SEF. The sample used for the analysis consists of 17907 groups consisting of 81852 individual loans. The most utilised time horizon used in the sample is the six-month loan ( $48.51 \%$ of the total) followed by the four-month loan $(30.71 \%)$.

\section{TABLE 1: Data summary}

\begin{tabular}{lcccccc}
\hline & \multicolumn{3}{c}{ Marang } & \multicolumn{3}{c}{ SEF } \\
\hline & Average & Maximum & Minimum & Average & Maximum & Minimum \\
No. of Members & 4,12 & 10 & 3 & 4,57 & 5 & 3 \\
Average Group Age(years) & 46,58 & 71,33 & 23,75 & 48,77 & 81,75 & 23,6 \\
Average Loan Size(Rands) & 2568,47 & 15000 & 700 & 2100,74 & 12760 & 500 \\
Loan Cycle & 5,30 & 34 & 1 & 6,04 & 30 & 1 \\
Homogeneity Score (Business) & 0,72 & 1 & 0,17 & N/A & N/A & N/A \\
Homogeneity Score (Industry) & 0,41 & 1 & 0,11 & N/A & N/A & N/A \\
\hline
\end{tabular}

Source: Small Enterprise Foundation and Marang Financial Services, authors' calculations

TABLE 2: Marang Financial Services Group Information

\begin{tabular}{ccccccc}
\hline $\begin{array}{c}\text { Number of } \\
\begin{array}{c}\text { Members in } \\
\text { Groups }\end{array}\end{array}$ & $\begin{array}{c}\text { Number of } \\
\text { Groups }\end{array}$ & $\begin{array}{c}\text { Sum of } \\
\text { Members }\end{array}$ & $\begin{array}{c}\text { Groups in } \\
\text { Rural Area }\end{array}$ & $\begin{array}{c}\text { Groups in } \\
\text { Semi-urban } \\
\text { Area }\end{array}$ & $\begin{array}{c}\text { Groups in } \\
\text { Urban Area }\end{array}$ & $\begin{array}{c}\text { Groups with } \\
\text { Male }\end{array}$ \\
\hline 3 & 739 & 2,217 & 532 & 136 & 71 & 92 \\
4 & 560 & 2,240 & 456 & 51 & 53 & 91 \\
5 & 493 & 2,465 & 424 & 31 & 38 & 111 \\
6 & 144 & 864 & 133 & 5 & 6 & 22 \\
7 & 38 & 266 & 35 & 2 & 1 & 10 \\
8 & 11 & 88 & 11 & 0 & 0 & 3 \\
\hline 10 & 7 & 63 & 7 & 0 & 0 & 1 \\
Grand Total & 1,994 & 8,223 & 1,600 & 225 & 169 & 331 \\
\hline
\end{tabular}


Muchnik \& Kollamparambil

Source: Marang Financial Services, authors' calculations

TABLE 3: Small Enterprise Foundation Group information

\begin{tabular}{cccccc}
\hline $\begin{array}{c}\text { Number of } \\
\text { Members in } \\
\text { Groups }\end{array}$ & $\begin{array}{c}\text { Number of } \\
\text { Groups }\end{array}$ & $\begin{array}{c}\text { Sum of } \\
\text { Members }\end{array}$ & Loan Type & $\begin{array}{c}\text { Number of } \\
\text { Loans }\end{array}$ & $\begin{array}{c}\text { Percentage of } \\
\text { loans }\end{array}$ \\
\hline 3 & 756 & 2268 & 4 Month & 7,549 & $30.71 \%$ \\
4 & 6171 & 24684 & 6 Month & 7,950 & $48.51 \%$ \\
5 & 10980 & 54900 & 8 Fortnights & 2,111 & $17.17 \%$ \\
Grand Total & 17907 & 81852 & 10 Months & 6 & $0.06 \%$ \\
& & & 12 Fortnights & 291 & $3.55 \%$ \\
\hline
\end{tabular}

Source: Small Enterprise Foundation, authors' calculations

This study is the first of its kind to use quantitative data to analyse the different determinants of repayment performance in South African microfinance programmes. As the data sets provided by SEF and Marang are not identical, the variables used for analysis are different between the two programmes.

\subsection{Small Enterprise Foundation variables}

\begin{tabular}{ll}
\hline BadPayment: & dependent variable in the logit estimation that is used to distinguish good repayment \\
& groups from bad repayment groups. A payment falls into the bad payment category if \\
& it has been written off as a bad debt or needed to be rescheduled. If the group made \\
& more than one untimely payment or short paid the loan it will fall into the bad \\
& payment category. \\
& BadPayment= l for bad repayment performance and; 0 for good repayment \\
& performance \\
& independent variable showing how many members are in the lending group. The groups \\
& consist of three, four or five members. The groups with fewer than three members are \\
& not included. The group size can potentially have two countervailing effects. On the \\
& one hand a small group can be easier to control and monitor, and on the other a larger \\
group can take advantage of the intergroup insurance mechanisms suggested by Zeller \\
(1998). Thus, the sign of this variable cannot be predicted. \\
Participatory Wealth Ranking score ("PWR"). PWR is a way of identifying who are the \\
poorest individuals in a community as well as who qualifies to be included in the \\
lending pool. Different households are ranked within the community by independent \\
groups and placed into different poverty-ranked categories. This is used to calculate \\
the poverty ranking among the poor. The poorest pool will always score lo0. The larger \\
the score the poorer the household. This variable represents the average poverty score \\
for the group. \\
independent variable represents the average age of the group. The ability of the \\
members of the group to monitor and pressure each other is expected to increase with \\
the average age of the group; thus this should have a positive impact on repayment \\
performance. \\
shows the average years in business for the group. We would expect the number of \\
years in business to improve the repayment performance. Borrowers who have more
\end{tabular}


years in business are supposed to have a greater ability to select more profitable business ventures as well as manage their projects better. Hence one can expect more years in business to positively impact repayment performance.

$\begin{array}{ll}\text { LoanSize: } & \text { sum of all the individual loans representing the group loan. } \\ \text { Mem3, Mem4, } & \text { these are separate dummy variables representing groups with three, four and five } \\ \text { Mem5: } & \text { members respectively. These variables will be used in a separate specification to } \\ & \text { this is the loan cycle. Each consecutive loan cycle will generally increase in loan size. } \\ \text { TC: } & \text { The groups consist of members on different loan cycles and this variable represents the } \\ & \text { average loan cycle for the group. } \\ & \text { dummy variable to identify which groups are completely homogeneous in business } \\ & \text { type. SameBus=l for groups where all members have the same business type and } 0 \\ \text { otherwise. } & \text { The more homogeneous the group members are in their business the easier the task of } \\ & \text { monitoring and evaluating the individual's entrepreneurial actions. This would } \\ \text { decrease the ability of the group member to take on riskier business practice. However, } \\ \text { since all the members are in the same industry there is less business risk diversification } \\ \text { within the group. The studies of Sharma and Zeller (1997) and Zeller (1998) found } \\ \text { negative relationships, which is contrary to research done by Wydick (1999), who found } \\ \text { a positive relationship. The more homogeneous the group, the more the peer pressure } \\ \text { that improves the repayment performance will be relaxed (more likely to collude). } \\ \text { However, there have been contrasting results that argue that group efficiency is } \\ \text { improved with group homogeneity, resulting in a less clear prediction. } \\ \text { time taken to repay loans, in months. } \\ \text { instalments paid by the group collectively. }\end{array}$

Source: Authors' analysis

${ }^{1}$ This is calculated at a group level, as the MFI concerns itself only about if the group has made its payment and doesn't keep track of the individual payments within the group.

${ }^{2}$ This variable is calculated by SEF based on local perceptions of poverty and used to prioritise lending to the poorest. It is calculated at a group level using the average of individual members. Details available in Simanowitz and Nkuna (1998).

${ }^{3}$ The Marang equation is:

$\operatorname{Pr}($ BadPmt $=1)=F(\beta[$ Members, Age, Rural, SemiUrban, Urban, Gender, AveloanSize, LC, SamelndScore, Samelnd, SameBusScore, SameBus]).

These explanatory variable aren't all used simultaneously, but are introduced in different specifications in result TABLE 4 .

The SEF equation is:

$\operatorname{Pr}($ BadPmt $=1)=F(\beta[S K$, Age, YIB, LoanSizeTot, SameBus, 8FT, 12FT, 4M, 6M, MemTot, Instalments, LC $])$

These explanatory variable aren't all used simultaneously but are introduced in different specifications in result TABLE 5 .

\subsection{Marang Financial Services Variables}

BadPayment, Age, LC, LoanSize and SameBus have the same description as detailed in section 5.1 above. The additional variables used in the Marang estimation are: 


\begin{tabular}{|c|c|}
\hline Members: & $\begin{array}{l}\text { independent variable showing how many members in the group. For Marang the number } \\
\text { of group members included in this study varies from } 3 \text { to } 10 \text { members in a group. }\end{array}$ \\
\hline \multirow[t]{3}{*}{ Rural: } & dummy variable representing whether the group is from a rural area. \\
\hline & Rural= 1 for groups from rural areas and 0 otherwise. \\
\hline & $\begin{array}{l}\text { According to Wenner (1995), more isolated communities have few sound credit } \\
\text { alternatives, resulting in better loan performance. However, Zeller (1998) found that } \\
\text { certain repayment characteristics are more prevalent in less remote areas. Rural } \\
\text { communities generally have stronger ties and therefore the peer pressure mechanism } \\
\text { should be more effective. In the South African context, expectations are aligned with } \\
\text { that of Wenner (1995), as there are generally fewer microfinance alternatives in rural } \\
\text { areas and individuals will become dependent on future credit provided by the } \\
\text { organisations. }\end{array}$ \\
\hline SemiUrban: & $\begin{array}{l}\text { dummy variable representing whether the group is from a semi-rural area. } \\
\text { SemiUrban=lfor groups from semi-urban areas and } 0 \text { otherwise. }\end{array}$ \\
\hline Urban: & $\begin{array}{l}\text { dummy variable representing whether the group is from an urban area. Urban=l for } \\
\text { groups from urban areas and } 0 \text { otherwise. }\end{array}$ \\
\hline Gender: & $\begin{array}{l}\text { dummy variable that identifies if the group is made up of females only or if there is one } \\
\text { or more males within the group. } 1:=\text { if one or more males; } 0 \text { if the group is } \\
\text { homogeneously female. Women are presumed to have a lower probability of default } \\
\text { than men because they are known to be financially more disciplined. }\end{array}$ \\
\hline SameBusScore: & $\begin{array}{l}\text { this is the same business homogeneity score. It is calculated by counting the number } \\
\text { of different business types and dividing that total by the number of members in the } \\
\text { group. The larger the homogeneity score value in the variable, the lower the actual } \\
\text { level of homogeneity in business type within the group. For example, if a group is made } \\
\text { up of five members representing two different business types, it will have a score of } \\
2 / 5=0.4 \text { another group that has five members with four different business types will } \\
\text { have a score of } 3 / 5=0.6 \text {. Clearly, the first group has a lower score and is more } \\
\text { homogeneous than the latter group. }\end{array}$ \\
\hline SamelndScore: & $\begin{array}{l}\text { this is the same industry homogeneity score. It is similar to the SameBusScore but at } \\
\text { the industry level. TABLE } 4 \text { shows the homogeneity score for industry and business type. } \\
\text { The score is grouped in } 0.1 \text { intervals and gives a sense of homogeneity distribution in } \\
\text { the sample. }\end{array}$ \\
\hline
\end{tabular}

\section{ESTIMATION}

The study uses a cross-section logit model that allows the dependent variable to be a binary qualitative variable. This econometric technique defines the dependent variable as either a 1 or a 0 to identify two distinct events in respect of which one wants to determine the respective probability. The specification consists of two probabilities associated with the dichotomous dependent variable, with the value 1 denoting perfect repayment and 0 denoting imperfect repayment. This makes it possible to take something qualitative in nature and transform it into a quantitative variable. This dependent variable distinguishes the perfect repayment group from the imperfect group and keeps them in separate categories.

The logit estimations technique will be used on both data sets individually. The variables in the Marang and SEF data sets are not exactly the same; however, there are several variables that are similar in both sets. 
TABLE 4: Homogeneity Score for Marang Financial Services

\begin{tabular}{ccccc}
\hline Score Range & $\begin{array}{c}\text { Count of } \\
\text { Homogeneity } \\
\text { Score (Industry) } \\
\text { Groups }\end{array}$ & $\begin{array}{c}\text { Percentage } \\
\text { Homogeneity } \\
\text { Score (Industry) }\end{array}$ & $\begin{array}{c}\text { Count of } \\
\text { Homogeneity } \\
\text { Score (Business) } \\
\text { Groups }\end{array}$ & $\begin{array}{c}\text { Percentage } \\
\text { Homogeneity } \\
\text { Score (Business) }\end{array}$ \\
\hline $0.1-0.2$ & 76 & $3.81 \%$ & 4 & $0.20 \%$ \\
\hline $0.2-0.3$ & 527 & $26.43 \%$ & 63 & $3.16 \%$ \\
$0.3-0.4$ & 488 & $24.47 \%$ & 91 & $4.56 \%$ \\
\hline $0.4-0.5$ & 219 & $10.98 \%$ & 108 & $5.42 \%$ \\
\hline $0.5-0.6$ & 254 & $12.74 \%$ & 193 & $9.68 \%$ \\
$0.6-0.7$ & 335 & $16.80 \%$ & 544 & $27.28 \%$ \\
$0.7-0.8$ & 41 & $2.06 \%$ & 261 & $13.09 \%$ \\
\hline $0.8-0.9$ & 4 & $0.20 \%$ & 179 & $8.98 \%$ \\
\hline $0.9-1.0$ & 50 & $2.51 \%$ & 551 & $27.63 \%$ \\
\hline Grand Total & 1994 & $100.00 \%$ & 1994 & $100.00 \%$ \\
\hline
\end{tabular}

Source: Authors' calculations

The equations can be described as follows:

$$
\left\{\begin{array}{c}
\operatorname{Pr}(\mathrm{Y}=1)=\mathrm{F}(\beta \mathrm{X}) \\
\operatorname{Pr}(\mathrm{Y}=0)=1-\mathrm{F}(\beta \mathrm{X})
\end{array}\right.
$$

where:

- $\quad y$ represents the dependent binary variable (BadPayment)

- $X$ the vector of explanatory variables (Marang ${ }^{1} ; S^{2} F^{2}$ )

- $\quad F$ the cumulative distribution function of the logistical law

- $\beta$ the vector of valued parameters

${ }^{1}$ The Marang equation is:

$\operatorname{Pr}($ BadPmt $=1)=F(\beta[$ Members, Age, Rural, SemiUrban, Urban, Gender, AveLoanSize, LC, SamelndScore, Samelnd, SameBusScore, SameBus]).

These explanatory variable aren't all used simultaneously, but are introduced in different specifications in result TABLE 4.

${ }^{2}$ The SEF equation is:

$\operatorname{Pr}($ BadPmt $=1)=F(\beta[S K$, Age, YIB, LoanSizeTot, SameBus, 8FT, 12FT, 4M, 6M, MemTot, Instalments, LC $])$

These explanatory variable aren't all used simultaneously but are introduced in different specifications in result TABLE 5 .

The coefficients in the logit model estimation indicate change in the log-odds in favour of success with one unit change in corresponding $X$ variables. 
a)

$$
P_{i}=\frac{1}{\left(1+e^{-z_{i}}\right)}=\frac{e^{z}}{1+e^{z}}
$$

where

$$
Z_{i}=\beta X_{i}
$$

a) The probability of bad payment

b) The probability of good payment b)

$$
1-P_{i}=\frac{1}{\left(1+e^{z_{i}}\right)}
$$

where

$$
Z_{i}=\beta X_{i}
$$

The odds-ratio is the ratio of the probability of bad payment to the probability of good payment. Estimation of odds-ratio coefficients enables a comparison of the relative significance of variables and identifies the more relevant determinants of loan repayment.

TABLE 5 provides the results of the regression for Marang Financial Services. The table consists of several different specifications of the logit model taking into account the possibility of multicollinearity given the correlation between variables (TABLE $A l$ in appendix). The main specification that is used in this analysis is specification one. We provide the odds-ratio of this model in the last column of TABLE 5 to enable a comparison of the relative significance of variables and identify the more relevant determinants of loan repayment.

The significant $(\alpha=1 \%$ ) positive Members variable indicates that larger groups negatively affect repayment performance. This is not surprising, as a smaller group is much easier to control and monitor. Previous studies came to varied conclusions with regard to the effect of the number of members in a group on its repayment ability; however, based on the results we may conclude that the insurance factor is less dominant than that of the peer monitoring mechanism.

Marang's lending methodology, like that of Grameen Bank, mainly targets women. The Gender variable is positive and significant, which means that groups with at least one male have a lower probability of repayment. Lending to women is a form of empowerment and they are known to be more financially disciplined and responsible. They are more exposed to social pressure, because it is viewed very negatively in the community if a woman doesn't repay her loan. The other element of group dynamics to consider is that men are generally more proud and don't want to be seen to be taking money from a woman to cover their loan.

In order to compare and contrast the impact of dwelling variables on repayment performance, we have considered the Rural variable as the benchmark dummy variable. The significant and negative Urban dummy variable indicates that the repayment performance of the urban borrowers are better than that of the rural borrowers. The SemiUrban dummy is not significant, indicating that their repayment performance does not differ significantly from that of the rural borrowers. This result coincides with the findings of Zeller (1998), who found that certain repayment-improving characteristics are more prevalent in less remote areas. The $L C$ and Age coefficients are both negative, which would mean that the larger the average loan cycle or the older the average group age, the better the repayment performance. However, this variable is not statistically significant in the estimation. LoanSize is positive and significant, which indicates that larger loans have a negative impact on repayment performance. 
TABLE 5: Marang Logit Regression Results: Dependent variable BadPayment

\begin{tabular}{|c|c|c|c|}
\hline Independent & Logit(1) & Logit(2) & Odds-ratio (1) \\
\hline Members & $\begin{array}{c}0.143 \star \star \star \\
(0.046)\end{array}$ & $\begin{array}{c}0.132 \star \star \star \\
(0.045)\end{array}$ & $\begin{array}{l}1.154 \star \star \star \\
(0.0537)\end{array}$ \\
\hline Age & $\begin{array}{l}-0.009 \\
(0.006)\end{array}$ & $\begin{array}{l}-0.009 \\
(0.006)\end{array}$ & $\begin{array}{c}0.991 \\
(0.0065)\end{array}$ \\
\hline SemiUrban & $\begin{array}{c}-0.616 \\
(0.155)\end{array}$ & $\begin{array}{r}-0.0586 \\
(0.155)\end{array}$ & $\begin{array}{c}0.9402 \\
(0.146)\end{array}$ \\
\hline Urban & $\begin{array}{c}-0.338 * \\
(0.182)\end{array}$ & $\begin{array}{c}-0.339 \star \\
(0.182)\end{array}$ & $\begin{array}{l}0.712 * \\
(0.130)\end{array}$ \\
\hline Gender & $\begin{array}{l}0.235^{\star} \\
(0.125)\end{array}$ & $\begin{array}{l}0.240 \star \\
(0.125)\end{array}$ & $\begin{array}{l}1.265^{\star} \\
(0.158)\end{array}$ \\
\hline LoanSize & $\begin{array}{l}7.6 e-05^{\star \star} \\
(3.4 e-05)\end{array}$ & $\begin{array}{l}7.6 e-05 \star \star \\
(3.4 e-05)\end{array}$ & $\begin{array}{c}1.000 \star \star \\
(3.4 e-05)\end{array}$ \\
\hline LC & $\begin{array}{c}-0.011 \\
(0.012)\end{array}$ & $\begin{array}{l}-0.009 \\
(0.012)\end{array}$ & $\begin{array}{l}0.9894 \\
(0.012)\end{array}$ \\
\hline SamelndScore & $\begin{array}{l}0.524 * \\
(0.276)\end{array}$ & & $\begin{array}{l}1.689 * \\
(0.467)\end{array}$ \\
\hline SameBusScore & & $\begin{array}{c}0.3745 \\
(0.229)\end{array}$ & \\
\hline Constant & $\begin{array}{c}-1.169 \\
(0.398)\end{array}$ & $\begin{array}{c}-1.184 * \star \star \\
(0.417)\end{array}$ & $\begin{array}{c}0.3104 * \star \star \\
(0.124)\end{array}$ \\
\hline Observations & 1994 & 1994 & 1994 \\
\hline LR Chi ${ }^{2}$ & 26.69 & 25.8 & 26.69 \\
\hline Prob $>C h i^{2}$ & 0.000 & 0.000 & 0.000 \\
\hline
\end{tabular}

Source: Authors' calculations

Standard errors in parentheses; ${ }^{\star \star \star} p<.01, * \star p<.05, * p<.1$

SamelndScore is positive and significant, indicating that the more homogeneous a group, the better the repayment performance. These findings are supported by Ghatak (1999) and Wydick (1999), who also found that the internal monitoring within the groups improved repayment performance. Bassen (2008) and Zeller (1998) produced contrasting results: their business homogeneity coefficients described opposite results. Zeller found that the diversification of business type improved the repayment probability. In the case of the industry variables, they capture the industry and business type, so it is possible that there is diversification of business type within the group, but they still have positive monitoring capabilities by being part of the same industry. SameBusScore, which looks at a similar characteristic of group homogeneity but at a more micro level (i.e. at a business type compared to the industry type level), is not found to be significant. 
The odds-ratio of the first specification indicates that among the significant variables the industry and gender homogeneity variables have the greatest impact on repayment performance.

We now turn to the results from the Small Enterprise Foundation data set, which are presented in TABLE 6. The table consists of several different specifications of the logit model taking into account the possibility of multicollinearity given the correlation between variables (TABLE A2 in appendix). The results are consistent across specifications. The main specification that is used in this analysis is specification one. We provide the odds-ratio of this model in the last column of TABLE 5 to enable a comparison of the relative significance of variables and identify the more relevant determinants of loan repayment.

In the case of SEF, the number of members in each group range from three to five. MemTot variable is found to be positive but not significant. Given the limited range of the variable we are not able to draw any conclusions on its impact on repayment. We therefore included a group dummy for each of the three groups in the second specification, but they were also not found to be significant.

The SK variable is very interesting, and this is the first article to use such a variable in terms of looking at repayment performance. The coefficient is negative and significant $(\alpha=1 \%)$. This implies that larger Participatory Wealth Ranking (PWR) scores have improved repayment performance. According to the PWR score, the higher the score the poorer the household, which means that poorer households have a better repayment performance. This result shows that lending to the poorest of the poor is not just a poverty-alleviation tool, but can also make good business sense. However, a possible reason for this result could be that the variable is biased by the distribution of the wealth ranking in the sample.

The lesson that formal banking institutions can take away from this result is the following: poorer individuals may indeed have a lower ability to service their debt financially when applying for loans, but the most important factor to look at is the client's ability to generate future cash flows from the intended business operations. A group of economically deprived individuals, if given opportunity, will work hard to reverse their situation. The commonality of poverty appears to be an important factor in their collective action, and in reality the group will have a common desire to overcome poverty and gain access to larger loans in the future. This coupled with their compulsory savings enforced by SEF policy is an important factor that will help reduce poverty in these communities as well as reduce the group members' dependence on credit, hence releasing them from the poverty trap.

The Age coefficient is significant and negative, which is in line with our prior expectations that groups with a larger average age should be more responsible and disciplined with their finances and business ventures. However, this result is not conclusive, as the Age variable was not significant in the Marang logit estimation. The YIB variable is not significant across different specifications. LoanSize and Instalments both capture a similar dynamic of loan repayment performance. Since these two variables are correlated they are introduced into the model separately as different specifications. LoanSize is found to be positive and significant across specifications, implying that larger loan values are associated with worse repayment performance. These results are in keeping with Marang results. The LC and SameBus coefficients are not significant in the estimation. 
The Duration variable is positive and significant, indicating that longer duration of loans adversely affects the repayment performance. This is to be expected, as a loan with a longer time horizon is associated with more risk.

TABLE 6: SEF Logit Regression Results: Dependent variable BadPayment

\begin{tabular}{|c|c|c|c|c|c|}
\hline Independent & Model(1) & Model(2) & Model(3) & Model(4) & $\begin{array}{l}\text { Odds- } \\
\text { ratio(1) }\end{array}$ \\
\hline SK & $\begin{array}{c}-0.009 * \star \star \\
(0.003)\end{array}$ & $\begin{array}{c}-0.009 \star \star \star \star \\
(0.003)\end{array}$ & $\begin{array}{c}-0.009 \star \star \star \\
(0.003)\end{array}$ & $\begin{array}{c}-0.009 * \star \star \\
(0.003)\end{array}$ & $\begin{array}{c}0.9903 * \star \star \\
(0.002)\end{array}$ \\
\hline Age & $\begin{array}{c}-0.034 \star \star \star \\
(0.011)\end{array}$ & $\begin{array}{c}-0.034 * \star \star \\
(0.011)\end{array}$ & $\begin{array}{c}-0.034 * \star \star \\
(0.011)\end{array}$ & $\begin{array}{c}-0.039 * \star \star \\
(0.010)\end{array}$ & $\begin{array}{c}0.9669 * \star \star \\
(0.010)\end{array}$ \\
\hline YIB & & & $\begin{array}{l}0.0804 \\
(0.019)\end{array}$ & $\begin{array}{c}0.0345 \\
(0.0222)\end{array}$ & \\
\hline LoanSize & $\begin{array}{c}0.0002 * \star \star \\
(5.7 e-05)\end{array}$ & $\begin{array}{l}0.0002 * \star \star \\
(5.7 e-05)\end{array}$ & & $\begin{array}{c}0.0002 * \star \star \\
(5.7 e-05)\end{array}$ & $\begin{array}{l}1.0002 * \star \star \\
(5.7 e-05)\end{array}$ \\
\hline SameBus & $\begin{array}{l}0.1599 \\
(0.240)\end{array}$ & $\begin{array}{c}0.016 \\
(0.240)\end{array}$ & $\begin{array}{l}0.1401 \\
(0.240)\end{array}$ & $\begin{array}{c}0.164 \\
(0.240)\end{array}$ & $\begin{array}{c}1.138 \\
(0.2818)\end{array}$ \\
\hline Duration & $\begin{array}{l}0.107 * \star \\
(0.0509)\end{array}$ & $\begin{array}{l}0.121 * \star \\
(0.0522)\end{array}$ & $\begin{array}{l}0.089 * * \\
(0.051)\end{array}$ & $\begin{array}{l}0.128 * \star \\
(0.241)\end{array}$ & $\begin{array}{l}1.112 * \star \\
(0.050)\end{array}$ \\
\hline Instalments & & & $\begin{array}{l}-0.000267 \\
(7.5 e-05)\end{array}$ & & \\
\hline LC & $\begin{array}{l}-0.0053 \\
(0.025)\end{array}$ & $\begin{array}{l}-0.006 \\
(0.025)\end{array}$ & & & $\begin{array}{c}0.9947 \\
(0.0255)\end{array}$ \\
\hline MemTot & $\begin{array}{c}0.042 \\
(0.150)\end{array}$ & & $\begin{array}{l}0.2251 \\
(0.152)\end{array}$ & $\begin{array}{c}0.0477 \\
(0.0151)\end{array}$ & $\begin{array}{c}1.042 \\
(0.156)\end{array}$ \\
\hline Mem3 & & $\begin{array}{l}-0.414 \\
(0.516)\end{array}$ & & & \\
\hline Mem4 & & $\begin{array}{c}0.045 \\
(0.178)\end{array}$ & & & \\
\hline Constant & $\begin{array}{c}-3.291 * \star \star \\
(0.810)\end{array}$ & & $\begin{array}{c}-3.491 * \star \star \\
(0.809)\end{array}$ & $\begin{array}{c}-3.098 * \star \star \\
(0.501)\end{array}$ & $\begin{array}{c}0.0372 * \star \star \\
(0.0255)\end{array}$ \\
\hline Observations & 17,907 & 17,907 & 17,907 & 17,907 & 17,907 \\
\hline $\begin{array}{l}\text { LR Chi2 } \\
\text { Prob>Chi2 }\end{array}$ & $\begin{array}{c}39.24 \star \star \star \\
0.000\end{array}$ & $\begin{array}{c}40.05 * \star \star \\
0.000\end{array}$ & $\begin{array}{c}46.56 * \star \star \\
0.000\end{array}$ & $\begin{array}{c}40.05 \star \star \star \\
0.000\end{array}$ & $\begin{array}{c}39.24 \star \star \star \\
0.000\end{array}$ \\
\hline
\end{tabular}

Source: Authors' calculations

Standard errors in parentheses; ${ }^{* \star *} p<.01, * \star p<.05, * p<.1$

The odds-ratio of the first specification indicates that among the significant variables the size of loan has the greatest impact on repayment performance, followed by Poverty Wealth Ranking and the age variables. 


\section{CONCLUSION}

This empirical article looks at the determinants of joint-liability lending repayment performance in South Africa. The analysis was conducted on the two largest microfinance group-lending organisations in the country using a logit regression model. The study tested explanatory variables that have been identified as determinants of repayment performance in other parts of the world as well as investigated the effects of some new variables. The goal of the research is to assist MFIs to refine and optimise the design of their lending structures to better understand the determinants of repayment performance and thus the sustainability of microfinance as a mechanism for poverty alleviation in South Africa.

The results show that large group sizes can have a negative impact on repayment performance due to imperfect flows of information between members, which creates the problem of information asymmetries, leading to less effective monitoring. Larger loan size is also found to have a negative impact on repayment performance.

This is the first article to use a Poverty Wealth Ranking score variable to investigate the impact of relative poverty levels within a community on repayment performance. The results show the ability of individuals with little or no collateral to be good borrowers. Formal institutions and policymakers should note that it is possible to lend to the poorest individuals in a community sustainably. Microenterprise loans give economically deprived individuals the opportunity to break out of their poverty trap with a focus on becoming self-sufficient.

The impact of group homogeneity is a contested area in the literature. This study used two variables to investigate the previous contrary hypothesises of group homogeneity on repayment performance. The findings indicate that the more homogeneous a group in industry type the better the repayment performance. The analysis did not find that the homogeneous business type variable was significant. As group homogeneity is frequently used as a methodological guideline for group formation in many microfinance programmes, more research in this area is needed in order to make conclusive recommendations for group structuring. It is also important to remember that the freedom of the group to self-select without restrictions plays an important role in the group lending system.

The analysis shows that groups with female members only have a better repayment performance than groups made up of a combination of males and females. Other findings include a better repayment performance for shorter time horizons, and less remote areas.

An interesting dynamic that has come out of joint-liability lending is the free-rider problem, where certain members of a group will continually cover portions of other individuals' repayments, as they are dependent on future credit. This might result in good borrowers dropping out of groups, which will have negative impact on repayment performance. It is suggested that these microfinance institutions consider a separate programme for individuals who have proved themselves through cycles of good repayment and should be given the opportunity to graduate to an individual lending status. This could also be used as a dynamic incentive. 


\section{Acknowledgements}

We would like to express our gratitude to Marang Financial Service and Small Enterprise Foundation for allowing the use of their data for the study. This study wouldn't have been possible without it. Further thanks to Francois Prudhomme at Marang Financial Services and to Andrew Becker and Mateo Zanetic from Small Enterprise Foundation for their assistance with understanding the data sets.

\section{LIST OF REFERENCES}

BANKSETA (2013). The Microfinance Review: From Microfinance to Financial Inclusion. Centre for Inclusive Banking in Africa, University of Pretoria.

Bassem, B. S., (2008). Determinants of Successful Group Loan Repayment: An Application to Tunisia. Journal of Sustainable Development in Africa, pp. 766-800.

Baumann, T. (2002). Small Enterprise Foundation, s.l.: The Urban Resource Centre.

Besley, T. \& Coate, S. (1995). Group lending, repayment incentives and social collateral. Journal of Development Economics, pp. 1-18.

Bhatt, N. \& Tang, S.-Y. (2002). Determinants of Repayment in Microcredit: Evidence from Programs in the United States. International Journal of Urban and Regional Research, 26(2), pp. 360-376.

Bhatt, N. \& Tang, S.-Y. (2002). Determinants of Repayments in Microcredit: Evidence from Programs in the United States. International Journal of Urban and Regional Research, pp. 360-376.

Calvin, B. \& Coetzee, G. (2009). A review of the South African Microfinance Sector volume //background papers: Section III-Market Supply, s.I.: Finmark Trust and the Centre for Micro Finance, University of Pretoria.

Calvin, B. \& Coetzee, G. (2009). A review of the South African Microfinance Sector: Successes, Challenges, and Policy Issues, s.I.: Finmark Trust and the Centre for Micro Finance, University of Pretoria.

Cassar, A., Crowley, L. \& Wydick, B. (2007). The Effect of Social Capital on Group Loan Repayment: Evidence from Field Experiments. The Economic Journal, 117, pp. F85-F108.

Daley-Harris, S. (2009). State of the Microcredit Summit Campaign Report 2009, Washington: Microcredit Summit Campaign.

Ghatak, M. (1999). Group lending, local information and peer selection. Journa/ of Development Economics, p. 27-50.

Godquin, M. (2004). Microfinance Repayment Performance in Bangladesh: How to Improve the Allocation of Loans by MFIs. World Development, pp. 909-1926.

Hermes, N. \& Lensink, R. (2007). The Empirics of Microfinance: What do we know? The Economic Journal, pp. Fl-Flo.

Hietalahti, J. and Linden, M. (2006). Socio-economic impacts of microfinance and repayment performance: a case study of the Small Enterprise Foundation, South Africa Progress in Development Studies, 6(3), pp. 201-210.

Jensen, L. (2011). The Millennium Development Goals Report, New York: United Nations, Department of Economic and Social Affairs of the United Nations Secretariat. 
Marang Financial Services - Micro Finance for Growth \& Development. Available at: http://www.marang.co.za/ [Accessed November 2012].

Mohane, H., Coetzee, G. \& Grant, W. (2002). The Effects of the Interest Rate Ceilings on the Micro Lending Market in South Africa, Working paper 2002-02 Department of Agricultural Economics, Extension and Rural Development, University of Pretoria.

Morduch, J. (1999). The Microfinance Promise. American Economic Association, pp. 1569-1614.

Porteous, D. J. \& Hazelhurst, $\varepsilon$. (2004). Banking on Change: Democratising Finance in South Africa 1994 - 2004, s.I.: Juta and Company Ltd.

Ruit, C. v. d. (2001). Micro-Finance, Donor Roles and Influence, and the Pro-Poor Agenda: The Cases of South Africa and Mozambique, s.l.: Microfinance Gateway.

Sharma, M. \& Zeller, M. (1997). Repayment Performance in Group-Based Credit Programs in Bangladesh: An Empirical Analysis. World Development, pp. 1731-1742.

Simanowitz, A. \& Nkuna, B. (998). Tshomisano Credit Programme Participatory Wealth Ranking Operational Manual, s.l.: The Small Enterprise Foundation.

Stewart, R. et al. (2010). What is the impact of Microfinance on the Poor?, s.l.: A systematic review of evidence from sub-Saharan Africa. Technical report. London: EPPI-Centre, Social Science Research Unit, University of London.

Stiglitz, J. E. (1990). Peer Monitoring and Credit Markets. The World Bank Economic Review, pp. 351366.

The Small Enterprise Foundation / Freeing the world of poverty. Available at: http://www.sef.co.za [Accessed November 2012].

The Urban Resource Centre (2003). Small Enterprise Foundation: South Africa's Pro-Poor Microfinance Lender. Community Microfinance Network Monograph No. 1.

Varian, H. R. (1990). Monitoring Agents with Other Agents. Journal of Institutional and Theoretical Economics, pp. 153-174.

Vuuren, F. J. v. (2011). Risk Management for Microfinance Institutions in South Africa, Pretoria: University of Pretoria.

Wenner, M. D. (1995). Group Credit: A Means to Improve Information Transfer and Loan Repayment Performance. The Journal of Development Studies, pp. 263-281.

Wydick, B. (1999). Can Social Cohesion Be Harnessed To Repair Market Failures? Evidence from Group Lendingin Guatemala. The Economic Journal, pp. 463-475.

Zeller, M. (1998). Determinants of Repayment Performance in Credit Groups: The Role of Program Design. Economic Development and Cultural Change, Intragroup Risk Pooling, and Social Cohesion, pp. 599-620. 


\section{APPENDIX}

TABLE Al: Pearson's correlation coefficient among Marang variables

\begin{tabular}{|c|c|c|c|c|c|c|c|}
\hline & Members & Age & LoanSize & $\angle C$ & SameBus & $\begin{array}{c}\text { SameBusS } \\
\text { core }\end{array}$ & Samelna \\
\hline Members & 1 & & & & & & \\
\hline Age & -0.049 & 1 & & & & & \\
\hline LoanSize & -0.069 & 0.162 & 1 & & & & \\
\hline LC & -0.152 & 0.349 & 0.047 & 1 & & & \\
\hline SameBus & -0.096 & 0 & 0.028 & 0.029 & 1 & & \\
\hline $\begin{array}{l}\text { SameBusS } \\
\text { core }\end{array}$ & -0.33 & 0.031 & -0.017 & 0.048 & -0.512 & 1 & \\
\hline Samelnd & -0.109 & -0.023 & 0.051 & -0.011 & 0.264 & -0.319 & 1 \\
\hline $\begin{array}{l}\text { SamelndSc } \\
\text { ore }\end{array}$ & -0.409 & 0.053 & -0.005 & 0.097 & -0.175 & 0.49 & -0.751 \\
\hline
\end{tabular}

TABLE A2: Pearson's correlation coefficient among S\&F variables

\begin{tabular}{|c|c|c|c|c|c|c|}
\hline & $S K$ & Age & $Y \mid B$ & $\angle C$ & SameBus & Instalments \\
\hline SK & 1 & & & & & \\
\hline Age & 0.009 & 1 & & & & \\
\hline YIB & -0.147 & 0.274 & 1 & & & \\
\hline LC & -0.119 & 0.288 & 0.749 & 1 & & \\
\hline SameBus & -0.023 & 0 & 0.088 & 0.069 & 1 & \\
\hline Instalments & -0.0529 & 0.135 & 0.348 & 0.545 & 0.012 & 1 \\
\hline LoanSize & -0.05 & 0.145 & 0.383 & 0.542 & 0.04 & 0.919 \\
\hline
\end{tabular}

